\title{
Upper Respiratory Infection Followed by Concurrent Sweet's Syndrome and Erythema Nodosum
}

\author{
Alemka Markotić1 ${ }^{1,2,3}$ (D) , Ivana Puškarić ${ }^{1}$, Tomislava Skuhala ${ }^{1,4}$ \\ ${ }^{1}$ University Hospital for Infectious Diseases „Dr. Fran Mihaljević“, Zagreb, Croatia \\ ${ }^{2}$ School of Medicine, University of Rijeka, Rijeka, Croatia \\ ${ }^{3}$ Catholic University of Croatia, Zagreb, Croatia \\ School of Dental Medicine, University of Zagreb, Zagreb, Croatia
}

ABSTRACT:

Sweet's syndrome (SS) is a rare inflammatory condition presented with fever, leukocytosis, erythematous, tender plaques and histology evidence of dense neutrophilic infiltration in the dermis. It appears mostly in women between age 30-60 years. Erythema nodosum (EN), a form of panniculitis, is manifested as erythematous painful rounded lumps and occurs 3-5 times more often in female patients in all age groups, but mostly between the second and the fourth decades of life. Although rare, concurrent occurrence of Sweet's syndrome and erythema nodosum is described and may be associated with autoimmune disorders, certain malignancies, gastrointestinal disease or upper respiratory tract infections. Here, we described 34-year-old saleswoman who developed concurrent Sweet's syndrome and erythema nodosum seven days after upper respiratory tract infection onset. During upper respiratory infection, she was treated with three-days azithromycin therapy, together with ibuprofen and paracetamol. Later, when she developed concurrent SS and EN, she was treated initially with clindamycin and prednisone $40 \mathrm{mg}$, followed by $60 \mathrm{mg}$ of prednisone after which the patient becomes afebrile with gradual rash regression. There is limited knowledge on concurrent SS and EN, their etiopathogenesis and association with different diseases, infections and /or medications. Concurrent SS and EN in our patient was probably triggered by the upper

OPEN ACCESS

Correspondence: Prof. Alemka Markotić MD PhD alemka.markotic@bfm.hr orcid.org/0000-0003-4104-7940

This article was submitted to RAD CASA - Medical Sciences as the Case report

Conflict of Interest Statement: The authors declare that the research was conducted in the absence of any commercial or financial relationships that could be construed as a potential conflict of interest.

Received: 5 November 2019 Accepted: 10 December 2019 Published: 17 December 2019

Citation: Markotić M, Puškarić I and Skuhala T. Upper Respiratory Infection Followed by Concurrent Sweet's Syndrome and Erythema Nodosum. RAD CASA- Medical Sciences. $540=48-49$ (2019): 71-74. https:// dx.doi.org/10.21857/mwo1vczw1y

Copyright (C) 2019 Markotić, Puškarić, Skuhala. This is an open-access article distributed under the terms of the Creative Commons Attribution License (CC BY). The use, distribution or reproduction in use, distribution or reproduction in other forums is permitted, provided the original author(s) and the copyright owners(s) are credited and that the original publication in this journal is cited, in accordance whit accepted adacemic practice. No use, distribution or reproduction is permitted which does not comply with these respiratory tract infection. Although, there is no evidence that azithromycin may induce SS or EN or both, it could be considered as a possible trigger alone or together with the upper respiratory tract infection.

KEYWORDS: upper respiratory infection, pharyngitis, Sweet's syndrome, erythema nodosum, azithromycin

\section{SAŽETAK:}

RESPIRATORNA INFEKCIJA GORNJIH DIŠNIH PUTOVA PRAĆENA ISTOVREMENO SWEETOVIM SINDROMOM I NODOZNIM ERITEMOM

Sweetov sindrom (SS) rijetko je upalno stanje koje se manifestira vrućicom, leukocitozom, eritematoznim, nježnim plakovima i histološkim dokazom guste neutrofilne infiltracije u dermisu. Pojavljuje se uglavnom u žena u dobi od 30-60 godina. Nodozni eritem (EN), oblik panikulitisa, očituje se bolnim, eritematoznim, zaobljenim potkožnim čvorovima i javlja se 3-5 puta češće u bolesnica u svim dobnim skupinama, ali uglavnom između drugog i četvrtog desetljeća života. Iako je rijetka, istodobna pojava Sweet-ovog sindroma i nodoznog eritema opisana je i može biti povezana s autoimunim poremećajima, određenim malignim bolestima, gastrointestinalnom bolešću ili infekcijama gornjih dišnih putova. Ovdje smo opisali 34-godišnju prodavačicu koja je razvila istodobni Sweetov sindrom i nodozni eritem sedam dana nakon početka infekcije gornjih dišnih putova. Tijekom infekcije gornjih dišnih puteva, liječena je trodnevnom terapijom azitromicinom, zajedno s ibuprofenom i paracetamolom. Kasnije, kad je razvila istodobno SS i EN, liječena je u početku klindamicinom i prednizonom od $40 \mathrm{mg}$, a zatim sa $60 \mathrm{mg}$ prednizona, nakon čega bolesnica postaje afebrilna s postupnom regresijom osipa. Malo se zna o istodobnom SS i EN, njihovoj etiopatogenezi i povezanosti s različitim bolestima, infekcijama i / ili lijekovima. Istodobni SS i EN u naše bolesnice vjerojatno je potaknut infekcijom gornjih dišnih puteva. Iako nema dokaza da azitromicin može izazvati SS ili EN ili oboje, moglo bi se pretpostaviti da bi mogao biti okidač sam ili zajedno s infekcijom gornjih dišnih puteva.

KLJUČNE RIJEČI: infekcija gornjih dišnih puteva, faringitis, Sweetov sindrom, nodozni eritem, azitromicin 


\section{INTRODUCTION}

Upper respiratory tract infections (URI) include the infection in nose, sinuses, pharynx, larynx, and the large airways and are leading cause of morbidity. Usually, they are caused by different viruses, mostly rhinoviruses, but also the influenza virus, adenovirus, enterovirus, and respiratory syncytial virus. Bacterial infections are also common and often pharyngitis could be caused by Streptococcus pyogenes, a Group A streptococcus ${ }^{1,2}$.

Sweet's syndrome (SS) is a rare inflammatory condition presented with fever, leukocytosis erythematous, tender plaques and histology evidence of dense neutrophilic infiltration in the dermis. Different diseases, including infectious diseases, malignancies and medications are associated with SS. It appears mostly in women between age 30-60 years ${ }^{3-5}$. There are major and minor criteria for diagnosis of SS (Figure 1) ) $^{6,7}$. For the treatment of patients with Sweet's syndrome systemic corticosteroids have been considered the primary option, but iodide or colchicine can also result in rapid resolution symptoms and lesions. In case that corticosteroids are contraindicated, indomethacin, clofazimine, dapsone, and cyclosporine can be administered $^{3,4}$

Erythema nodosum (EN), a form of panniculitis, is manifested as erythematous painful rounded lumps, $1-6 \mathrm{~cm}$ in diameter and occurs 3-5 times more often in female patients in all age groups, but mostly between the second and the fourth decades of life. EN is usually located symmetrically on the anterior surface of the lower extremities, but can also spread to the upper extremities and neck. It does not ulcerate and resolves without scarring. Streptococcal pharyngitis is the most common trigger of EN, which appears 2-3 weeks after infection resolution. Mycoplasma, Chlamydia, Mycobacterium, Yersinia spp., Coccidioides and Histoplasma caused infections could be followed by EN as well. Other medical conditions, which could be linked to EN development are: sarcoidosis, medication including antibiotics, inflammatory bowel diseases and sometimes pregnancy. If an infectious agent triggered EN, antibiotic therapy can be administered and non-steroidal anti-inflammatory agents are usually given. In case that some medication was responsible for the occurrence of EN, it should be stopped. The most common drugs that cause erythema nodosum are: oral contraceptives, sulfonamides and penicillin. However, despite investigation, no underlying cause is found in most erythema nodosum patients ${ }^{8}$.

Although rare, concurrent occurrence of Sweet's syndrome and erythema nodosum is described and may be associated with autoimmune disorders, certain malignancies, gastrointestinal disease. A case of a young male with a recent streptococcal infection was also described $^{9-16}$.

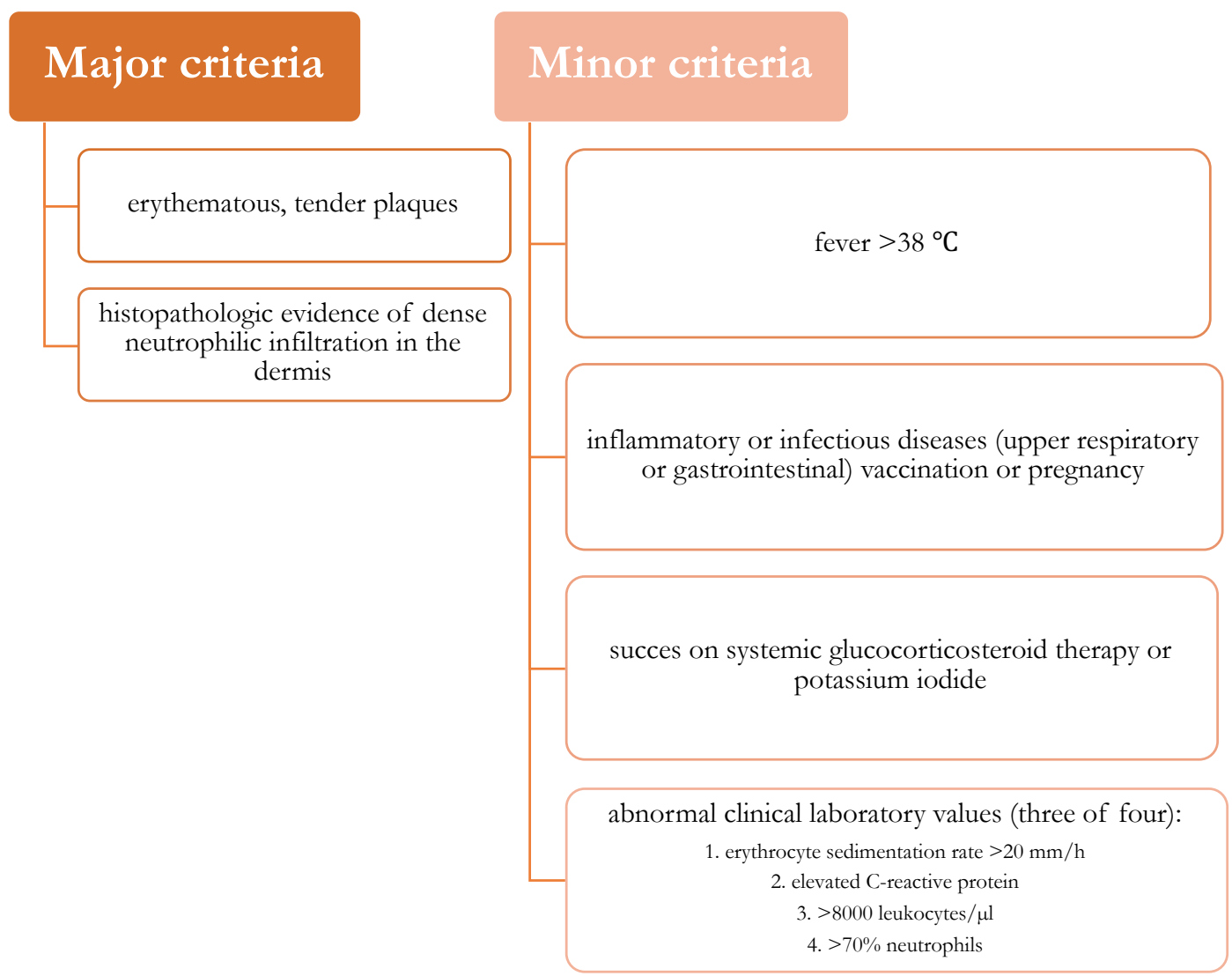

Figure 1. Figure 1. Major and minor diagnostic criteria for classic Sweet's syndrome based on fulfilling both major and two of the four minor criteria6,7. 


\section{CAse Report}

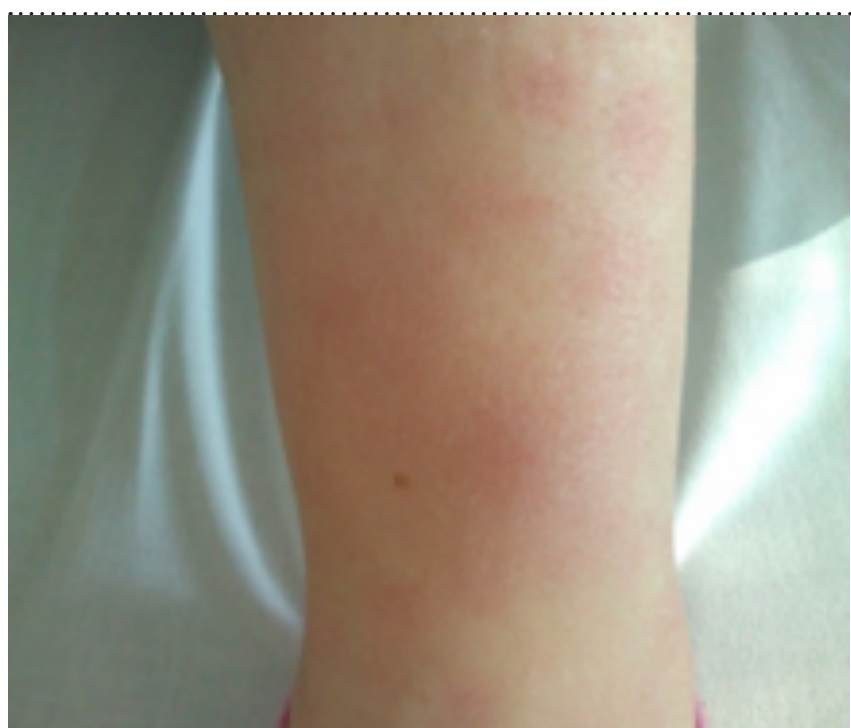

A

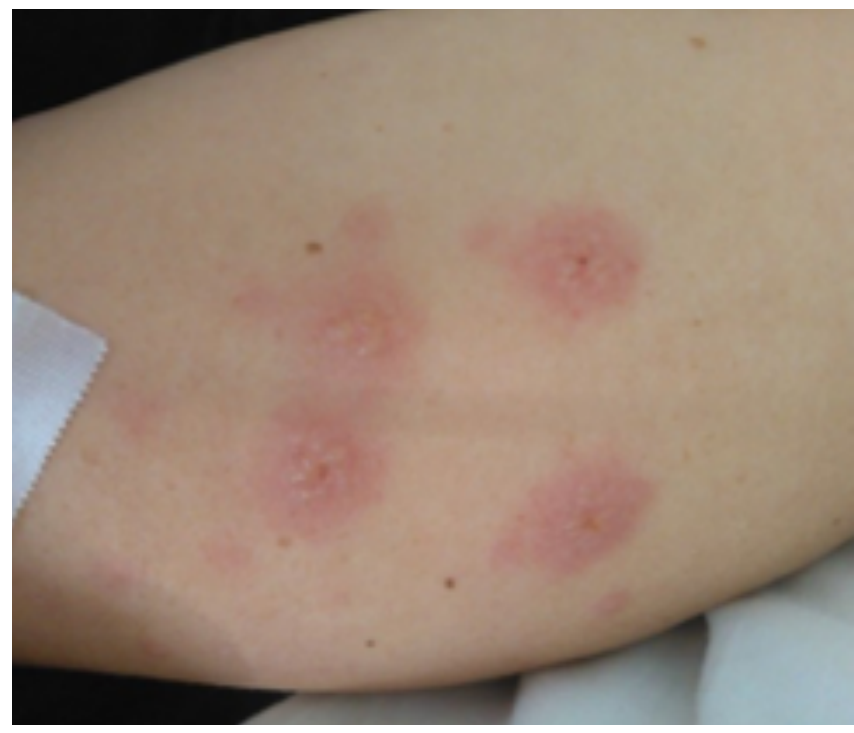

C

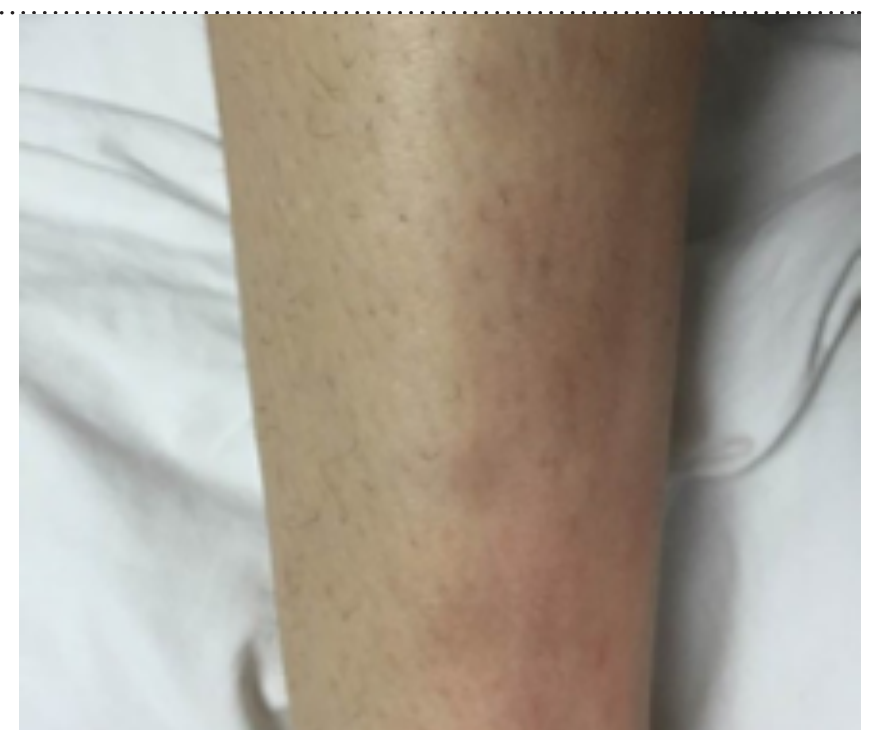

$\mathrm{B}$

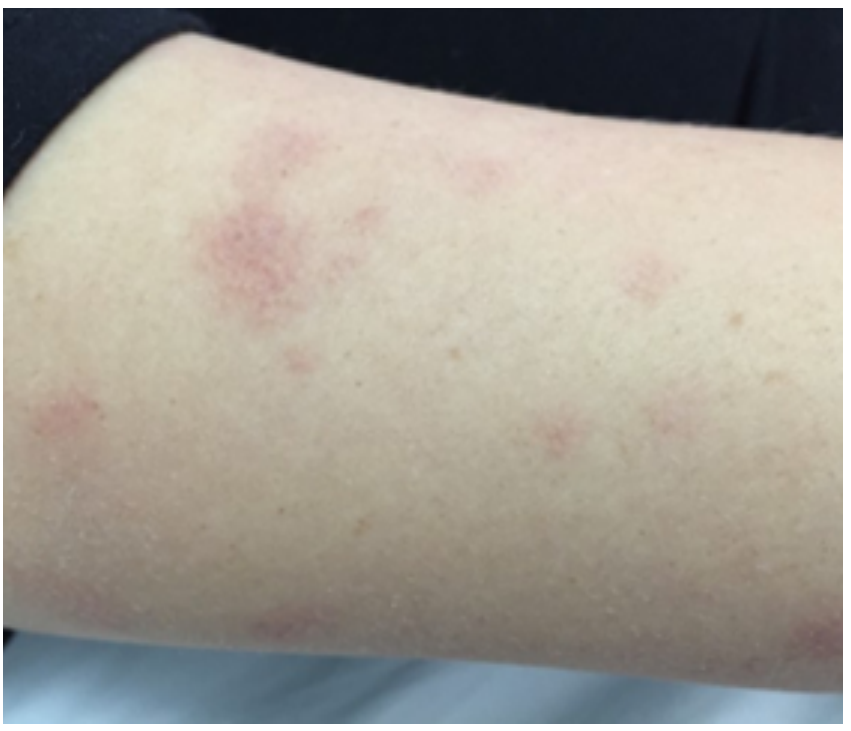

$\mathrm{D}$

Figure 2. Rounded lumps (erythema nodosum) on the skin of the patient's lower leg, three (A) and ten days after the rash onset (B); Annular plaques and pustules developed on the skin of patient's forearm three $(C)$ and ten days after the rash onset (D).

\section{CASE REPORT}

In 34-year-old saleswoman, the disease began eight days before admission to the hospital with a sore throat that lasted for the five days. On the sixth day after the upper respiratory tract symptoms onset, she became febrile up to $40{ }^{\circ} \mathrm{C}$ with chills and shivering. Next day she noticed a rash on the body and hands with mild pain and she was admitted to the hospital day after. Two days before admission she completed her three-days azithromycin therapy, taking ibuprofen and paracetamol as well. In childhood, she had contracted varicella and had lung tuberculosis at the age of 12 . She had no chronic illnesses and was not taking therapy for chronic illnesses. Her daughter had a respiratory, possibly viral infection a week ago. She stated that she was allergic to amoxicillin clavulanic acid.

On admission, she is conscious, febrile (38.5 C), normotensive $(110 / 70 \mathrm{mmHg})$, with neat pulse and respiratory frequency. Rounded lumps, suggestive of erythema nodosum were observed on the skin of the lower legs of the patient, together with the annular plaques and pustules $(0.5-1 \mathrm{~cm}$ in diameter) developed on the skin of patient's forearm (Figure $2 \mathrm{~A}, \mathrm{C}$ ) and very few at the trunk and neck. The conjunctival injection is recorded on both sides. Later, during the day, she became highly febrile up to $41 \mathrm{C}$.

She had high sedimentation rate $(70 \mathrm{~mm} / \mathrm{h})$ and C-reactive protein (CRP) was $197 \mathrm{mg} / \mathrm{l}$, with 8.800 leukocytes/ $\mu \mathrm{l}$. Chest X-ray was normal and a slightly enlarged liver and polyp in the gallbladder were recorded on an abdominal ultrasound. On the second day of hospitalization, a skin biopsy was taken from the annular papule on the forearm and histopathologic evidence of neutrophilic infiltration in the dermis was confirmed later on. Initially, she was treated with clindamycin, and prednisone $40 \mathrm{mg}$. Three days later, sedimentation rate was $40 \mathrm{~mm} / \mathrm{h}$ and CRP was $70 \mathrm{mg} / \mathrm{l}$. Five days after admission, the patient was still febrile up to $38.5 \mathrm{Q}$ and the prednisone dose was increased to $60 \mathrm{mg}$, after which the patient becomes afebrile with gradual rash regression (Figure $2 \mathrm{~B}, \mathrm{D}$ ).

\section{Discussion}

Although etiology of SS or EN are not known, both syndromes could be triggered with upper respiratory infections or medications and associated with autoimmune or malignant diseases. Both are also reactive dermatoses with some similar clinical manifestations and histopathological findings, which could be successfully solved with corticosteroid therapy 3-5. Concurrent SS and EN are rare, but are described in the literature in connection with autoimmune or malignant diseases and also some respiratory, mostly streptococcal infections ${ }^{9-13}$.

Here we presented concurrent SS and EN in 34-years old, previously healthy woman with preceding upper respiratory tract infection 
treated with azithromycin. We presumed that concurrent SS and EN in our patient was triggered with respiratory infection, but there is also possibility to be induced by antibiotic therapy. There is evidence in the literature that SS or EN are associated with some respiratory or gastrointestinal infections, including recent description of 29-year old Mexican who developed concurrent SS and EN possibly after the upper respiratory tract infection ${ }^{9-13}$. So far, there is no evidence in the literature that SS or EN could be induced by ibuprofen or paracetamol, which our patient took during the upper respiratory infection. Recent publication, however, described SS induced by an oral acetaminophen-codeine suspension and tablets, following repair of a facial fracture $^{17}$. Also, no azithromycin therapy was associated with SS or/ and EN so far and here we have no proof that this could be the case in our patient as well. Previously it was stated that tetracycline, minocycline, or clindamycin may be associated with $\mathrm{SS}^{18,19}$. The therapy with oral prednisone was successful in our patient and skin rash was almost completely gone in three weeks of follow up.

\section{CONCLUSION}

There is limited knowledge on concurrent SS and EN, their etiopathogenesis and association with different diseases, infections and /or medications. Here, we presented a concurrent SS and EN in 34-years old women, which was probably triggered by the upper respiratory tract infection. Although, there is no evidence that azithromycin may induce SS or EN or both, it could be considered as a possible trigger alone or together with the upper respiratory tract infection.

\section{AUTHOR CONTRIBUTIONS:}

All authors listed have made a substantial, direct and intellectual contribution to the work, and approved it for publication.

\section{LITERATURE:}

1. Zeng L, Zhang L, Hu Z, Ehle EA, Chen Y, Liu L, Chen M. Systematic review of evidence-based guidelines on medication therapy for upper respiratory tract infection in children with AGREE instrument. PLoS One. 2014;9(2):e87711.

2. Civljak R, Tot T, Falsey AR, Huljev E, Vranes J, Ljubin-Sternak S. Viral pathogens associated with acute respiratory illness in hospitalized adults and elderly from Zagreb, Croatia, 2016 to 2018. J Med Virol. 2019;91(7):1202-1209.

3. Heath MS, Ortega-Loayza AG. Insights Into the Pathogenesis of Sweet's Syndrome. Front Immunol. 2019;10:414. doi: 10.3389/fimmu.2019.00414. eCollection 2019.

4. Marzano AV, Borghi A, Wallach D, Cugno M. A Comprehensive Review of Neutrophilic Diseases. Clin Rev Allergy Immunol. 2018;54(1):114-130.

5. Volpe M. Sweet Syndrome Associated with Upper Respiratory Infection and Amoxicillin Use. Cureus. 2016;8(4):e568.

6. Su WP, Liu HN. Diagnostic criteria for Sweet's syndrome. Cutis. 1986;37:167-74.

7. Nofal A, Abdelmaksoud A, Amer H, Nofal E, Yosef A, Gharib K, Albalat W, Eldesouky F, Ebrahim HM, Abdelshafy AS, Fayed H. Sweet's syndrome: diagnostic criteria revisited. J Dtsch Dermatol Ges. 2017;15(11):1081-1088.

8. Schwartz RA, Nervi SJ. Erythema nodosum: a sign of systemic disease. Am Fam Physician. 2007;75(5):695-700.

9. Moreau E, Peiffert D, Schmutz JL, Granel-Brocard F, Bursztejn AC. Sweet syndrome and erythema nodosum in a case of anal canal cancer during concomitant radiochemotherapy. Eur J Dermatol. 2019. doi: 10.1684/ejd.2019.3628.

10. Cohen PR, Holder WR, Rapini RP. Concurrent Sweet's syndrome and erythema nodosum: a report, world literature review and mechanism of pathogenesis. J Rheumatol. 1992;19(5):814-20.

11. Wilkinson SM, Heagerty AH, English JS. Acute febrile neutrophilic dermatosis in association with erythema nodosum and sarcoidosis. Clin Exp Dermatol. 1993;18(1):47-9.

12. Gillott TJ, Whallett AJ, Struthers GR, Ilchyshyn A. Concurrent Sweet's syndrome (acute febrile neutrophilic dermatosis), erythema nodosum and sarcoidosis. Clin Exp Dermatol. 1997;22(1):54-6.

13. Wasson S, Govindarajan G, Folzenlogen D. Concurrent occurrence of Sweet's syndrome and erythema nodosum: an overlap in the spectrum of reactive dermatoses. Clin Rheumatol. 2006;25(2):268-72.

14. Harris T, Henderson MC. Concurrent Sweet's syndrome and erythema nodosum. J Gen Intern Med. 2011;26(2):214-5.

15. Qiao J, Wang Y, Bai J, Wu Y, Fang H. Concurrence of Sweet's syndrome, pathergy phenomenon and erythema nodosum-like lesions. An Bras Dermatol. 2015;90(2):237-9.

16. Muscardin LM, Paolino G, Cota C, Didona D, Panetta C, Donati P. Concurrent Sweet's Syndrome and erythema nodosum in a patient with bilio-pancreatic diversion. G Ital Dermatol Venereol. 2017;152(4):392-394.

17. Bradley LM, Higgins SP, Thomas MM, Rodney IJ, Halder RM. Sweet syndrome induced by oral acetaminophen-codeine following repair of a facial fracture. Cutis. 2017;100(3):E20-E23.

18. Corazza M, Lauriola MM, Borghi A, et al. Sweet's syndrome: A retrospective clinical, histopathological and immunohistochemical analysis of 11 cases. Acta Derm Venereol 2008;88(6):601-6. 19. Contrucci RB, Martin DB. Sweet syndrome: A case report and review of the literature. Ear Nose Throat J. 2015;94(7):282-4. 